\title{
Influence of wood-derived biochar on the compactibility and strength of silt loam soil
}

\author{
Ahmed Ahmed*, Yvan Gariepy, and Vijaya Raghavan \\ Department of Bioresource Engineering, McGill University, 21,111 Lakeshore Road, Sainte-Anne-de-Bellevue, \\ Quebec, Canada, H9X 3V9
}

Received September 3, 2016; accepted March 3, 2017

\begin{abstract}
A b s t r a c t. Biochar is proven to enhance soil fertility and increase crop productivity. Given that the influence of biochar on soil compaction remains unclear, selected physico-mechanical properties of soil amended with wood-derived biochar were assessed. For unamended silt loam, the bulk density, maximum bulk density, optimum moisture content, plastic limit, liquid limit, and plasticity index were $1.05 \mathrm{Mg} \mathrm{m}^{-3}, 1.69 \mathrm{Mg} \mathrm{m}^{-3}, 16.55,17.1$, 29.3 , and $12.2 \%$, respectively. The penetration resistance and shear strength of the unamended silt loam compacted in the standard compaction Proctor mold and at its optimum moisture content were $1800 \mathrm{kPa}$ and $850 \mathrm{kPa}$, respectively. Results from amending the silt loam with $10 \%$ particle size ranges $(0.5-212 \mu \mathrm{m})$ led to relative decreases of $18.1,17.75,66.66$, and $97.4 \%$ in bulk density, maximum bulk density, penetration resistance, and shear strength, respectively; a $26.8 \%$ relative increase in optimum moisture content; along with absolute increases in plastic limit, liquid limit, and plasticity index of 5.3, 13.7, and $8.4 \%$, respectively. While the biochar-amended silt loam soil was more susceptible to compaction, however, soil mechanical impedance enhanced.

$\mathrm{K}$ e y w o r d s: biochar, particle size, bulk density, proctor compaction, plastic and liquid limit, penetration resistance, soil shear strength
\end{abstract}

\section{INTRODUCTION}

Biochar is produced by pyrolysis, a process whereby biomass material is decomposed in the absence of oxygen at temperatures ranging from 250 to $700^{\circ} \mathrm{C}$ (Yuan et al., 2014). The organic starting material can be drawn from a variety of types of biomass, including wood chips, crop residues, manure, and animal waste. Pyrolysis conditions and feedstock material are responsible for biochar characteristics such as chemical composition, surface chemistry,

*Corresponding author e-mail: ahmed.ahmed@mail.mcgill.ca nutrient composition, adsorption capacity, cation exchange capacity (CEC), $\mathrm{pH}$, and physical structure (Cimò et al., 2014).

Soil compaction is defined as densification of soil whereby air-filled porosity is reduced, causing deterioration in soil processes. Subsoil compaction is a cumulative process leading to soil packing just below the topsoil (Harris, 1971). As compaction increases soil mechanical impedance, it adversely affects the elongation and proliferation of roots (Boone and Veen, 1994). These changes might result in the alteration of moisture and nutrient availability to crops, thereby increasing or decreasing the agricultural soil productivity.

The changes in soil physical properties lead to changes in soil state under compaction (Chen and Weil, 2011). Soil particle density is $2.6 \mathrm{Mg} \mathrm{m}^{-3}$ regardless of its particle size, while for wood-derived biochar (WBC) with a particle size of less than $70 \mu \mathrm{m}$ it ranges between 0.6 and $1.6 \mathrm{Mg} \mathrm{m}^{-3}$, depending on the wood source (Hu et al., 2016; Yargicoglu et al., 2015). Due to the relatively low true density of biochar, its amendment to soils have been reported to decrease soil bulk density $(\rho)$ (Abel et al., 2013; Andrenelli et al., 2016; Bayabil et al., 2015; Castellini et al., 2015; Liu et al., 2016; Obia et al., 2016). For example, Reddy et al. (2015) found the specific gravity of silty clay, WBC (particle sizes $<420 \mu \mathrm{m}$ ), and silty clay amended with 5,10 , and $20 \%$ WBC to be 2.6, 0.81, 2.1, 2.0, and 1.8, respectively. Soil optimum moisture content for compaction $\left(\theta_{\text {opt }}\right)$ is the moisture content at which soil reaches its maximum bulk density $\left(\rho_{\max }\right)$ for a given applied specific load. It has been established that soil compressibility decreases with an increase 
in the WBC amendment and with a decrease in WBC particle size (Reddy et al., 2015). Carter (1990) found crop yield to be correlated to the soil relative bulk density (RBD), i.e., $\frac{\rho}{\rho_{\max }}$ (Håkansson and Lipiec, 2000). Similarly, Zhao et al.

(2010) showed that a maximum tree height was achieved when $0.60 \leq \frac{\rho}{\rho_{\max }} \leq 0.68$, but these trees were somewhat stunted when $0.78 \leq \frac{\rho}{\rho_{\max }} \leq 0.87$.

The plastic limit $\left(\theta_{p l}\right)$ is the water content, in percent, at which soil can no longer be deformed by rolling into a $3.2 \mathrm{~mm}$ thread. The moisture content at which soil passes from a liquid to a plastic state is called the liquid limit $\left(\theta_{l l}\right)$ (Das and Kassimali, 2002). Determined for soils with more than $10 \%$ clay content, the plasticity index $\left(P I=\theta_{l l}-\theta_{p l}\right)$ increases as the soil clay content increases. However, soils with less than $10 \%$ clay content can be plastic if organic matter is present (Keller and Dexter, 2012). These consistency limits can provide a means of describing the degree and kind of cohesion and adhesion between soil particles and any biochar amendments with respect to the resistance of the soil to deform or rupture. As the PI value of soil increases, the range of moisture over which the soil is susceptible to compaction by external forces increases (Aksakal et al., 2013). Amendment with 6\% coal fly ash $(P S<2 \mathrm{~mm})$ significantly $(\mathrm{p}<0.05)$ decreased the $\theta_{l l}$ and increased the $\theta_{p l}$ of clay soil and led to a decrease in soil $P I$ of $35 \%$ (Lu et al., 2014). In another study, WBC ( $P S<2$ $\mathrm{mm}$ ) amended to clay loam soil at a rate of $6 \%$ significantly $(\mathrm{p}<0.05)$ increased the $\theta_{l l}$ of the soil by relatively $8 \%$ and the soil $\theta_{p l}$ decreased by $14.7 \%$ resulting in a $59 \%$ increase in the PI (Zong et al. 2016). There is a significant and positive correlation between $\theta_{o p t}$ and $\theta_{p l}$ and $\theta_{l l}$ (Barzegar et al., 2004; Dexter and Bird, 2000; Mosaddeghi et al., 2009; Mueller et al., 2003). The $\theta_{p l}, \theta_{l l}$, and PI can be estimated from the $\theta_{o p t}$, as well as the soil clay, silt, and organic matter (OM) content (Wagner et al. 1992). Soil $\rho_{\max }$ can be estimated from $\theta_{p l}$ for fine-grained soils (Mueller et al., 2003; Oren, 2014). However, there is no existing model to estimate the consistency limits from the soil particle sizes and the percentage of WBC in soils.

Dexter and Bird (2000) defined soil workability for tillage as 'the water content at which tillage produced the greatest proportion of small aggregates'. Soil workability is related to soil consistency limits and/or Proctor compaction test data (Muller et al., 1990; Wagner et al., 1992). The $\theta_{o p t}$ or $0.9 \theta_{p l}$ is considered optimal for tillage practices (Dexter and Bird, 2000). Soil structure damage is prevented when tillage occurs at the soil optimal moisture content for tillage (Mueller et al., 2003). The consistency limits of the soil are crucial not only to estimate compressibility and the optimum workable water content range for tillage operations (Zong et al., 2016) but also in agricultural soil irrigation management (Smedema 1993). The Atterberg limits and the Proctor compaction test parameters are agro- nomically relevant in terms of compaction hazard for soils and tillage. In summary, an increase in soils $\theta_{l l}, \theta_{p l}$, and $\theta_{o p t}$ valuesnot only results in less compactable and more easily tilled soils, but also a wider workable soil moisture range and greater resistance to mechanical forces. Therefore, the first objective of this study was to determine the effects of WBC application on the consistency limits and the Proctor compaction test parameters of a silt loam soil.

The incorporation of OM into compacted soils reduces their $\rho$ (Ohu et al. 1985), and results in a decrease in soil penetration resistance (PR), resulting, in turn, in an increase in root proliferation in compacted soils (Dexter, 2004; Ohu et al., 1985). Soil PR values exceeding 2000 $\mathrm{kPa}$ are associated with restricted root growth (Singh and Malhi, 2006). Busscher et al. (2010, 2011) showed the application of $44 \mathrm{Mg} \mathrm{ha}^{-1}$ of pecan shell-derived biochar $(2 \% \mathrm{dwb})$ to decrease the PR (measured at $\theta=10 \%$ ) of a fine loamy sand from 2.9 to $1.18 \mathrm{MPa}$. This biochar amendment raised the soil $\rho$ from 1.45 to $1.52 \mathrm{Mg} \mathrm{m}^{-3}$ (Busscher et al., 2010; 2011). Bekele et al. (2015) also showed the PR of a loamy soil to be lowered by a WBC amendment. In contrast, Eastman (2011) found a $25 \mathrm{Mg} \mathrm{ha}^{-1}$ WBC amendment not to have any significant effect on a silt loam soil PR one year after incorporation (Eastman, 2011). On the other hand, Mukherjee et al. (2014) found the PR of a silt loam soil amended with WBC to unexpectedly increase after 2 years, attributing this increase to the influence of post-amendment farm operations on soil physical properties.

Zong et al. (2016) showed WBC $(P S<2 \mathrm{~mm})$ to have a relativity lower cohesion $(c)$ and greater angle of internal friction $(\varphi)$ than a clay loam soil. These differences significantly reduced $c$ and increased $\varphi$ of the clay loam soil amended with WBC at a rate of $6 \%$. Also, the tensile strength of the clay loam soil decreased from 466 to $233 \mathrm{kPa}$ with the amendment of $6 \% \mathrm{WBC}$. These changes were attributed to the alteration in the soil pore structure and the degree of water saturation of the soil amended with biochar (Zong et al. 2016). In another study, the tensile strength of a clayey soil decreased from 937 to $353.5 \mathrm{kPa}$ with the amendment of WBC at a rate of $6 \%$ dwb (Lu et al., 2014). The shear strength (SS) of a silty clay soil was increased with an increase in the biochar amendment rate from 5 to $10 \% \mathrm{dwb}$, as well as with a decrease in biochar particle size from 4.76 to $0.42 \mathrm{~mm}$ (Reddy et al., 2015). Since the influence of WDB amendments on the strength of compacted soils is still unclear, the second objective of this this study was to determine the PR and SS of a compacted silty loam amended with WBC.

\section{MATERIALS AND METHODS}

The biochar in this study was produced by thermal decomposition of forest wastes, including maple (Acer sp.) wood, at $500^{\circ} \mathrm{C}$. This biochar was purchased from a local market. The brand name of the biochar is Maple Leaf ${ }^{\circledR}$ Charcoal (Charbon de Bois Feuille d'Érable Inc., Sainte- 
T a b l e 1. Bulk density $(\rho)$ and percent change in $\rho(\Delta \rho)$ of silty loam after amendment with WBC of different particle size ranges, at different rates

\begin{tabular}{|c|c|c|c|c|c|c|}
\hline \multirow{4}{*}{$\begin{array}{l}\text { Level of biochar } \\
\text { amendment } \\
\text { (\% dwb) }\end{array}$} & \multicolumn{6}{|c|}{ Biochar particle diameter range $(\mu \mathrm{m})$} \\
\hline & \multicolumn{2}{|c|}{$\mathrm{PS}_{1}$} & \multicolumn{2}{|c|}{$\mathrm{PS}_{2}$} & \multicolumn{2}{|c|}{$\mathrm{PS}_{3}$} \\
\hline & \multicolumn{2}{|c|}{$0.5-212$} & \multicolumn{2}{|c|}{$212-425$} & \multicolumn{2}{|c|}{$425-850$} \\
\hline & $\rho\left(\mathrm{Mg} \mathrm{m}^{-3}\right)$ & $\Delta \rho(\%)$ & $\rho\left(\mathrm{Mg} \mathrm{m}^{-3}\right)$ & $\Delta \rho(\%)$ & $\rho\left(\mathrm{Mg} \mathrm{m}^{-3}\right)$ & $\Delta \rho(\%)$ \\
\hline 2 & 0.98 & -7 & 1.02 & -3 & 1.03 & -2 \\
\hline 5 & 0.91 & -14 & 1.00 & -5 & 1.01 & -4 \\
\hline 10 & 0.86 & -19 & 0.90 & -14.5 & 0.93 & -12 \\
\hline
\end{tabular}

Values of $\rho$ in bold differ significantly $(\mathrm{p} \leq 0.05)$ from non-amended silt loam soil. $\rho$ of the silt loam soil is $1.05 \mathrm{Mg} \mathrm{m}^{-3}$.

Christine d'Auvergne, QC). The silt loam soil (SLS) was collected from the A horizon $(0-0.2 \mathrm{~m})$ of a field (coordinates 45.413919 - 73.941469) on the Macdonald Campus Farm, McGill University (Sainte-Anne-de-Bellevue, QC). The soil was air-dried at room temperature and then ground to pass through a $2 \mathrm{~mm}$ sieve.

Soil particle size analysis was quantified according to the procedures outlined in ASTM (1984). Biochar particles size was determined by laser diffraction analysis following procedures outlined in (Müller et al., 2004)

Biochar was ground in a blender and sieved in a fume hood to achieve the desired particle sizes. Dry soil and biochar were mixed for $20 \mathrm{~min}$ in a soil mixer with the desired composition of biochar in the soil on a dry weight basis (dwb) to achieve a homogeneous mixture. The compostion of biochar in the silt loam soil were chosen to be 2 , 5 , or $10 \%$. These rates of biochar composition in the soil were selected to understand the behaviour of the soil as biochar is added. The application rate corresponded to an application rate in the field of $75,187.5$, and $375 \mathrm{Mg} \mathrm{ha}^{-1}$, assuming a bulk density of soil in the field of $1250 \mathrm{~kg} \mathrm{~m}^{-3}$ with an application depth of $30 \mathrm{~cm}$.

The $\rho$ determinations were performed by dividing the oven-dry mass of the silt loam, WBC, or WBC-amended silt loam by its volume. The $\rho_{\max }$ and $\theta_{\text {opt }}$ were determined through the standard Proctor compaction test, following the procedure of ASTM (2007).

Soil consistency limits were determined according to (ASTM 2010).

The PR of the compacted silt loam in the standard Proctor mold was determined by a penetrometer (FieldScout, SC900 Soil Compaction Meter) according to ASAE (2013) with a penetrometer cone diameter of $12.83 \mathrm{~mm}$ and a cone angle of $30^{\circ}$. Torvane (Humboldt, H4221 Geovane Soil Shear Strength Tester) was used to determine the SS of the soil compacted in the compaction mold according to ASAE (2016).

Analysis of variance (ANOVA) and the Duncan Multiple Range Test were used for testing mean differences SAS, (v. 9.2, SAS Institute, Cary, NC).

\section{RESULTS AND DISCUSSION}

The sieve analysis showed that the silt loam was a wellgraded soil having 100, 66, 47.2, 12.1, 8, and 4.6\% finer after sieves of $2000,850,425,150,106$, and $75 \mu \mathrm{m}$, respectively. The hydrometer analysis showed that the silt loam soil contained $17 \%$ clay, $77 \%$ silt, and $6 \%$ sand. The WBC was sieved into three particles size (PS) ranges: $0.5-212 \mu \mathrm{m}$ $\left(\mathrm{PS}_{1}\right), 212-425 \mu \mathrm{m}\left(\mathrm{PS}_{2}\right)$, and $425-850 \mu \mathrm{m}\left(\mathrm{PS}_{3}\right)$. The smallest particle size of $0.5 \mu \mathrm{m}$ was determined by a laser diffraction method.

The $\rho$ of the silt loam, and $\mathrm{PS}_{1}, \mathrm{PS}_{2}$, and $\mathrm{PS}_{3}$ of the biochars were $1.05,0.29,0.31$, and $0.33 \mathrm{Mg} \mathrm{m}^{-3}$, respectively. New values of $\rho$ and percent change in $\rho(\Delta \rho)$ upon amendment of the silt loam with different rates of WBC of different particle size ranges are shown in Table 1.

The $\rho_{\max }$ and the corresponding $\theta_{o p t}$ of the silt loam were $1.69 \mathrm{Mg} \mathrm{m}^{-3}$ and $16.5 \%$, respectively. Figure 1 shows the influence on the $\rho_{\max }$ and corresponding $\theta_{\text {opt }}$ of the amended soil, when silt loam was amended with WBC of different particle sizes $\left(\mathrm{PS}_{1}, \mathrm{PS}_{2}\right.$ or $\left.\mathrm{PS}_{3}\right)$ each at a rate of $10 \%(\mathrm{dwb})$. Figure 2 shows the influence on the amended soil $\rho_{\max }$ and corresponding $\theta_{\text {opt }}$, when silt loam was amended with $\mathrm{PS}_{1}$ WBC at different rates $(2,5,10 \% \mathrm{dwb})$.

Table 2 illustrates the differences in relative bulk densities of the silt loam soil amended with WBC. The silt loam soil has an $\frac{\rho}{\rho_{\max }}$ of 0.62 and, as expected, the WBC amendment led to no significant change $(\mathrm{p}<0.01)$ in the soil $\frac{\rho}{\rho_{\max }}$. Therefore, given that the values of $\frac{\rho}{\rho_{\max }}$ fall in the safe range of $0.60 \leq \frac{\rho}{\rho_{\max }} \leq 0.68$ (Håkansson and Lipiec, 2000), no structural damage was found to occur.

The influence of the variation in particle size and application rate of WBC amended to silt loam on $\rho_{\max }$ and $\theta_{\text {opt }}$ values, along with their percent change, are presented in Table 3. Applications of $\mathrm{PS}_{1}, \mathrm{PS}_{2}$, and $\mathrm{PS}_{3}$ size $\mathrm{WBC}$ 


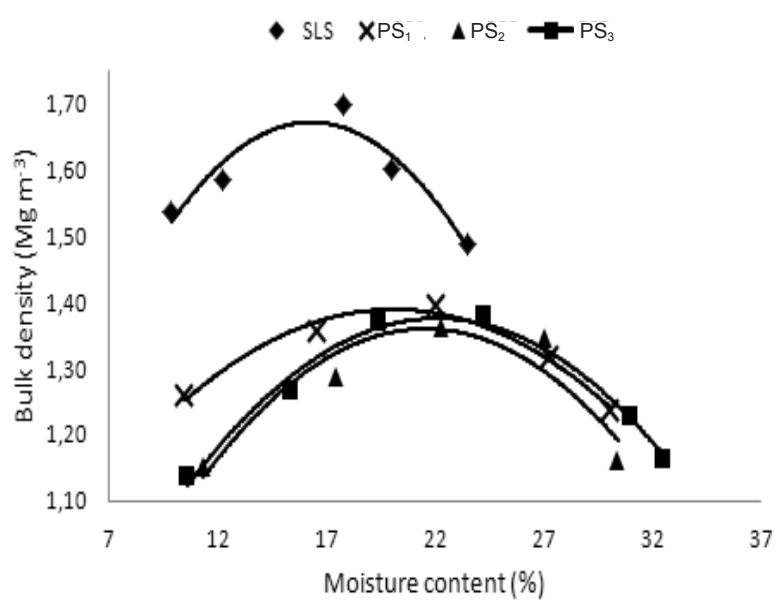

Fig. 1. Influence of amending a silt loam soil with $10 \%$ biochar of different particle diameters (e.g., $\mathrm{PS}_{1}, \mathrm{PS}_{2}$, and $\mathrm{PS}_{3}$ ) on the compaction curves of the soil.

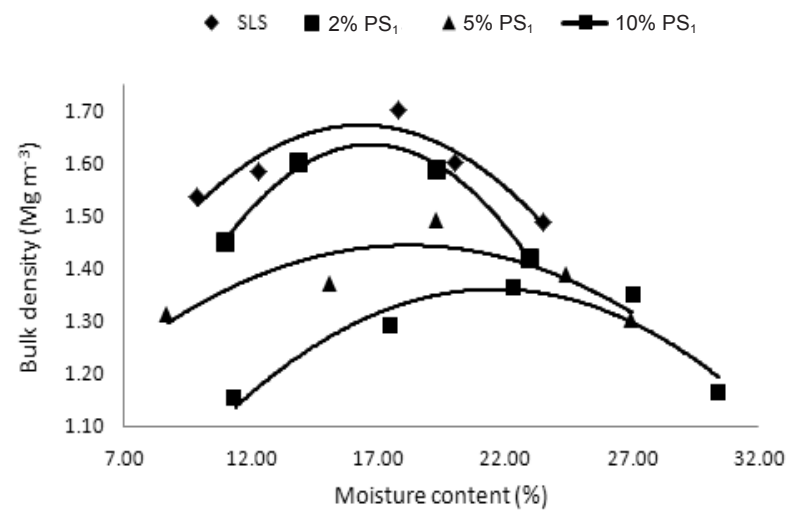

Fig. 2. Influence of amending a silt loam soil with biochar of a specific particle diameter range (e.g., $\mathrm{PS}_{1}$ ) at different rates (e.g., 2, 5, 10\%) on the compaction curves of the soil.

T a b l e 2. Effect of the WBC particle size and application rate on silt loam maximum bulk density $\left(\frac{\rho}{\rho_{\max }}\right)$ and optimum mois-
ture content $\left(\theta_{\text {opt }}\right)$

\begin{tabular}{cccc}
\hline \multirow{2}{*}{\begin{tabular}{c} 
Level \\
of biochar \\
amendment \\
\cline { 2 - 4 }$(\%$ dwb $)$
\end{tabular}} & \multicolumn{3}{c}{ Biochar particle diameter range $(\mu \mathrm{m})$} \\
\cline { 2 - 4 } & $0.5-212 \mu \mathrm{m}$ & $212-425 \mu \mathrm{m}$ & $425-850 \mu \mathrm{m}$ \\
\hline 2 & 0.6 & 0.62 & 0.65 \\
5 & 0.59 & 0.7 & 0.67 \\
10 & 0.61 & 0.66 & 0.68 \\
\hline
\end{tabular}

Relative bulk density $\frac{\rho}{\rho_{\max }}$ of non-amended silt loam were 0.62 . at a rate of $5 \%$ and $10 \%(\mathrm{dwb})$ had a statistically significant $(\mathrm{p} \leq 0.05)$ effect on $\rho_{\max }$ and $\theta_{o p t}$ compared to the non-amended silt loam, clearly indicating that the addition of $\mathrm{WBC}$, regardless of particle sizes, to soil extended the range of the soil workability without causing compaction.

The $\theta_{p l}, \theta_{l l}$, and $P I$ of the non-amended SLS were 17.1, 29.3 , and $12.2 \%$, respectively. Table 4 illustrates the variations in consistency limits of the SLS amended with WBC at various rates and of different particle sizes. The effect of WBC application on soil PI was not consistent. The PI values for the $\mathrm{PS}_{1}-\mathrm{WBC}$ amendments varied with application doses. Amendment of the silt loam with 5 or $10 \%$ $\mathrm{PS}_{1}$-WBC led to a significant $(\mathrm{p} \leq 0.05)$ increase in $P I$ over the non-amended soil. In contrast, for the same amendment rates, the $\mathrm{PS}_{2}-\mathrm{WBC}$ and $\mathrm{PS}_{3}-\mathrm{WBC}$ amendments led to no significant $(\mathrm{p}>0.05)$ increase in $P I$. Given the important role of the value of $\theta_{l l}$ in $P I$, the aforementioned difference in the response can be attributed to the relatively lesser increase in $\theta_{l l}$ of the $\mathrm{PS}_{2}-\mathrm{WBC}$ and $\mathrm{PS}_{3}$-WBC-amended silt loam, compared to that of the $\mathrm{PS}_{1}-\mathrm{WBC}$ amended soil. The increase in $\theta_{p l}$ for the three particle sizes ranges is on the order of 1-7 units, whereas the increase in $\theta_{l l}$ for the $\mathrm{PS}_{1}-\mathrm{WBC}$ amendment was greater than that for either the $\mathrm{PS}_{2}-\mathrm{WBC}$ or $\mathrm{PS}_{3}-\mathrm{WBC}$ amendments. This inconsistency minimized the effect of WBC amendment on $P I$ values for the $\mathrm{PS}_{2}-\mathrm{WBC}$ or $\mathrm{PS}_{3}-\mathrm{WBC}$-amendments. According to Mapfumo and Chanasyk (1998), a $P I<7$ indicates low plasticity of a soil, whereas $7<P I<17$ indicates medium plasticity, and $P I>17$ indicates high plasticity. Unlike clay soils, which exhibit high plasticity and are therefore highly prone to compaction, the slit loam used in this study exhibited medium plasticity and was therefore - given the narrow moisture range within which deformation could occur - less prone to severe compaction. The WBC-amended silt loam became less plastic as WBC itself is non-plastic (Downie et al., 2009). Moreover, the increase in $\theta_{p l}$ and $\theta_{l l}$ could be attributed to the high absorptive capacity of the WBC for water due to its significant void content and large surface area (Guo et al., 2014). This increased affinity to water would result in a WBC-amended soil requiring more water to behave in a plastic or liquid manner than the non-amended silt loam. In conclusion, $\mathrm{PS}_{1}-\mathrm{WBC}$ applied at rates of 5 and $10 \%$ increases $P I$, thereby increasing the range of moisture within which soils are most susceptible to compaction, and, in turn, decreasing the workability of the soil under tillage operations by increasing structural damage to the soil. On the other hand, the same amendments decreased the $\rho_{\max }$, which is a positive influence of improving compacted soil. Increasing the water content at $\theta_{o p t}$ over $\theta_{l l}$ and $\theta_{p l}$ may imply that the soil is more easily tilled in higher moisture content conditions without any deformation and also provides a higher workable range. 
T a b l e 3. Effect of WBC particle size and application rate on silt loam maximum bulk density $\left(\rho_{\max }\right)$ and optimum moisture content $\left(\theta_{\text {opt }}\right)$

\begin{tabular}{|c|c|c|c|c|c|c|c|c|c|c|c|c|}
\hline \multirow{4}{*}{$\begin{array}{l}\text { Level of } \\
\text { biochar } \\
\text { amend- } \\
\text { ment } \\
\text { (\% dwb) }\end{array}$} & \multicolumn{12}{|c|}{ Biochar particle diameter range $(\mu \mathrm{m})$} \\
\hline & \multicolumn{4}{|c|}{$\mathrm{PS}_{1}$} & \multicolumn{4}{|c|}{$\mathrm{PS}_{2}$} & \multicolumn{4}{|c|}{$\mathrm{PS}_{3}$} \\
\hline & \multicolumn{4}{|c|}{$0.5-212$} & \multicolumn{4}{|c|}{$212-425$} & \multicolumn{4}{|c|}{$425-850$} \\
\hline & $\begin{array}{l}\rho_{\max } \\
(\mathrm{Mg} \\
\left.\mathrm{m}^{-3}\right)\end{array}$ & $\begin{array}{c}\Delta \rho_{\max } * \\
(\%)\end{array}$ & $\begin{array}{l}\theta_{o p t} \\
(\%)\end{array}$ & $\begin{array}{c}\Delta \theta_{o p t} \\
(\%)\end{array}$ & $\begin{array}{l}\rho_{\max } \\
(\mathrm{Mg} \\
\left.\mathrm{m}^{-3}\right)\end{array}$ & $\begin{array}{c}\Delta \rho_{\max } * * \\
(\%)\end{array}$ & $\begin{array}{l}\theta_{o p t} \\
(\%)\end{array}$ & $\begin{array}{l}\Delta \theta_{o p t} \\
(\%)\end{array}$ & $\begin{array}{l}\rho_{\max } \\
(\mathrm{Mg} \\
\left.\mathrm{m}^{-3}\right)\end{array}$ & $\begin{array}{c}\Delta \rho_{\max } \\
(\%)\end{array}$ & $\begin{array}{l}\theta_{o p t} \\
(\%)\end{array}$ & $\begin{array}{l}\Delta \theta_{o p t} \\
(\%)\end{array}$ \\
\hline 2 & 1.64 & -3 & 18 & +8.33 & 1.64 & -3 & 16.7 & +1.2 & 1.59 & -6 & 17.9 & +7.8 \\
\hline 5 & 1.54 & -9 & 19.5 & +15.4 & 1.42 & -16 & 18.7 & +11.8 & 1.51 & -11 & 19 & +13.2 \\
\hline 10 & 1.39 & -17.75 & 21 & +21.4 & 1.36 & -20 & 22 & +1.37 & 1.37 & -19 & 22.5 & +26.7 \\
\hline
\end{tabular}

*Relative $\%$ difference, **absolute difference $(\%)$, values of $\rho_{\max }$ and $\theta_{\text {opt }}$ in bold differ significantly $(\mathrm{p} \leq 0.05)$ from non-amended silt loam soil. $\rho_{\max }$ and $\theta_{\text {opt }}$ of non-amended silt loam were $1.69 \mathrm{Mg} \mathrm{m}^{-3}$ and $16.5 \%$ respectively.

T a b l e 4. Influence of WBC particle size and application rate on silt loam plasticity parameters

\begin{tabular}{|c|c|c|c|c|c|c|c|c|c|c|c|c|}
\hline \multirow{5}{*}{$\begin{array}{l}\text { Level of } \\
\text { biochar } \\
\text { amend- } \\
\text { ment } \\
(\% \text { dwb) }\end{array}$} & \multicolumn{12}{|c|}{ Biochar particle diameter range $(\mu \mathrm{m})$} \\
\hline & \multicolumn{4}{|c|}{$\mathrm{PS}_{1}$} & \multicolumn{4}{|c|}{$\mathrm{PS}_{2}$} & \multicolumn{4}{|c|}{$\mathrm{PS}_{3}$} \\
\hline & \multicolumn{4}{|c|}{$0.5-212$} & \multicolumn{4}{|c|}{$212-425$} & \multicolumn{4}{|c|}{$425-850$} \\
\hline & $\theta_{p l}{ }^{*}$ & $\theta_{l l}^{*}$ & $P I^{*}$ & $\Delta P I^{* *}$ & $\theta_{p l}$ & $\theta_{l l}$ & $P I$ & $\triangle P I$ & $\theta_{p l}$ & $\theta_{l l}$ & $P I$ & $\triangle P I$ \\
\hline & \multicolumn{12}{|c|}{$(\%)$} \\
\hline 2 & 18.0 & 31.0 & 13 & +0.8 & 17 & 29.7 & 12.7 & +0.5 & 18 & 30.1 & 12.1 & -0.1 \\
\hline 5 & 20.3 & 39.3 & 19 & +6.8 & 19.7 & 36.0 & 16.7 & +4.5 & 20 & 32.0 & 12.0 & -0.2 \\
\hline 10 & 22.4 & 43.0 & 20.6 & +8.4 & 22.3 & 37.3 & 15.0 & +2.8 & 23.7 & 35.0 & 11.3 & -0.9 \\
\hline
\end{tabular}

$\theta_{p l}, \theta_{l l}$ and $P I$ of non-amended silt loam are 17.1, 29.3 and 12.2\%, respectively. Other explanations as in Table 3.

The PR and SS of the silt loam were determined under conditions of $\rho_{\max }$ and $\theta_{\text {opt }}$, i.e., at the peak of the compac-

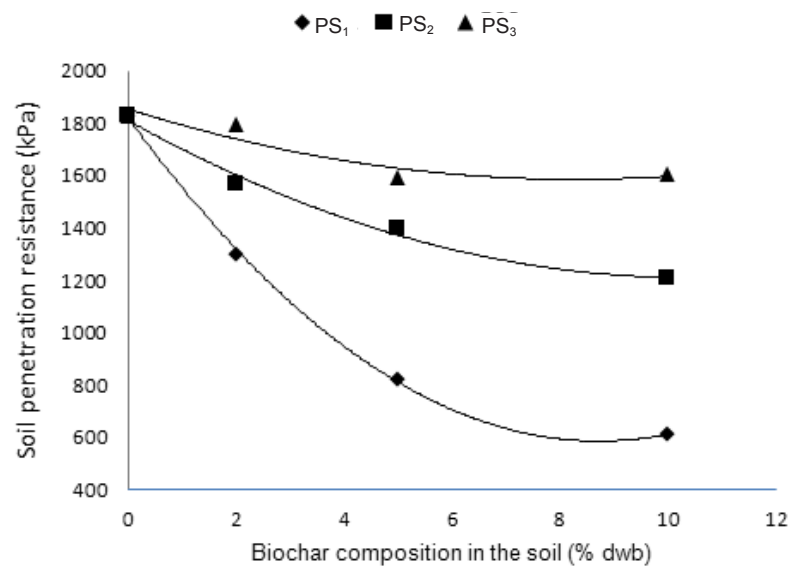

Fig. 3. Influence of the $\mathrm{WBC}$ amendment rate and particle size on the penetration resistance of a WBC amended silt loam. tion curve. The compacted silt loam had a PR of $1827 \mathrm{kPa}$ while the silt loam amended with $10 \% \mathrm{PS}_{1}-\mathrm{WBC}$ had a PR of $610 \mathrm{kPa}$. The decrease in PR measured at the soil $\rho_{\max }$ and $\theta_{\text {opt }}$ for silt loam amended with 2, 5, or $10 \% \mathrm{WBC}$ of different particle size ranges $\left(\mathrm{PS}_{1}, \mathrm{PS}_{2}\right.$, and $\left.\mathrm{PS}_{3}\right)$ is illustrated in Fig. 3. It should be noted here that the amended soil $\theta_{\text {opt }}$ and $\rho_{\max }$ were different at each PR and SS measurement point due to the presence of WBC in the soil matrix. The compacted non-amended silt loam exhibited a SS of $858 \mathrm{kPa}$, compared to the much lower SS of the silt loam amended with $10 \% \mathrm{PS}_{1}-\mathrm{WBC}(221 \mathrm{kPa})$. This decrease in $\mathrm{SS}$ is attributable to the reduced cohesion of silt loam particles amended with the carbonaceous material. Also, the amended silt loam $\left(10 \% \mathrm{PS}_{1}-\mathrm{WBC}\right)$ was compacted at $\theta_{\text {opt }}=$ $21.4 \%$, whereas the non-amended silt loam was compacted at $\theta_{\text {opt }}=16.5 \%$. The differences in the moisture content of the soil when the shear vane test was conducted resulted in a decrease in the shear strength value of the compacted soil (Fig. 4). 


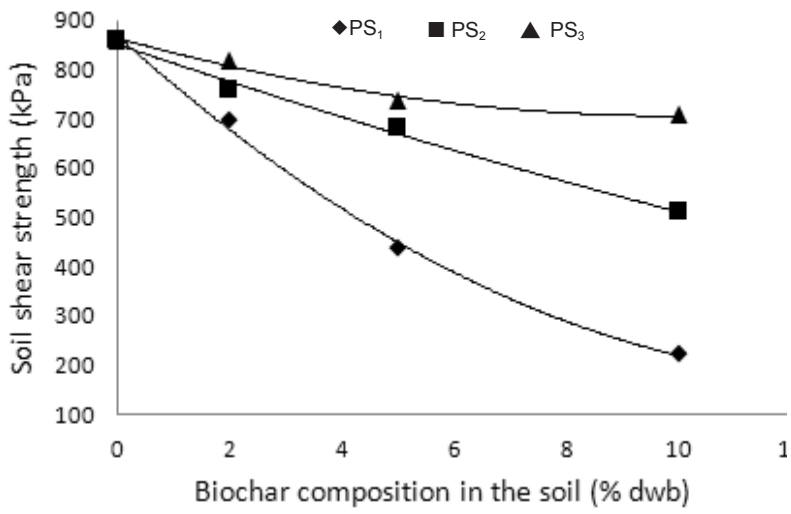

Fig. 4. Influence of the WBC amendment rate and particle size on the shear strength of a WBC-amended silt loam.

\section{CONCLUSIONS}

1. Biochar-amended soil showed a decline in bulk density and maximum bulk density and an increase in optimum moisture content relative to the non-amended soil. Moreover, the plastic limit and liquid limit were altered by the presence of biochar in the soil matrix. These changes in soil mechanical properties might adversely affect soil workability; therefore, this parameter should be quantified before modeling begins.

2. Specific particle sizes and quantities of biochar applied to a particular soil texture should be investigated and a predictive equation should be developed to recommend the quantity and particle size of biochar to be applied to a specific soil texture to improve its mechanical properties and, consequently, soil workability.

3 . The influence of biochar on the changes in soil maximum bulk density and optimum moisure content resulted in a decrease in the penetration resitance and shear strength of compacted soil measured at the soil maximum bulk density and optimum moisure content. The shear strength within a soil matrix is the result of interparticle resistance. Until now, data on the effect of biochar on the penetration resitance and shear strength values along the compaction curve for soils amended with varying particle sizes of WBC were not available.

4. Before modeling techniques are employed, further investigations are required to fully assess the effects on soil porosity and strength of amending different compactionprone soils.

Conflict of interest: The Authors do not declare conflict of interest.

\section{REFERENCES}

Abel S., Peters A., Trinks S., Schonsky H., Facklam M., and Wessolek G., 2013. Impact of biochar and hydrochar addi- tion on water retention and water repellency of sandy soil. Geoderma, 202-203, 183-191. doi: 10.1016/j.geoderma. 2013.03.003.

Aksakal E.L., Angin I., and Oztas T., 2013. Effects of diatomite on soil consistency limits and soil compactibility. Catena, 101, 157-163.

Andrenelli M.C., Maienza A., Genesio L., Miglietta F., Pellegrini S., Vaccari F.P., and Vignozzi N., 2016. Field application of pelletized biochar: Short term effect on the hydrological properties of a silty clay loam soil. Agricultural Water Management, 163, 190-196. doi: 10.1016/j.agwat. 2015.09.017.

Atkinson C.J., Fitzgerald J.D., and Hipps N.A., 2010. Potential mechanisms for achieving agricultural benefits from biochar application to temperate soils: A review. Plant Soil, 337(1), 1-18. doi: 10.1007/s11104-010-0464-5.

Barzegar A.R., Hashemi A.M., Herbert S.J., and Asoodar M.A. 2004. Interactive effects of tillage system and soil water content on aggregate size distribution for seedbed preparation in Fluvisols in southwest Iran. Soil Till. Res., 78(1), 45-52. doi: 10.1016/j.still.2004.01.002.

Bayabil H.K., Stoof C.R., Lehmann J.C., Yitaferu B., and Steenhuis T.S., 2015. Assessing the potential of biochar and charcoal to improve soil hydraulic properties in the humid Ethiopian Highlands: The Anjeni watershed. Geoderma, 243-244, 115-123. doi: 10.1016/j.geoderma. 2014.12.015.

Bekele A., Roy J.L., and Young M.A., 2015. Use of biochar and oxidized lignite for reconstructing functioning agronomic topsoil: Effects on soil properties in a greenhouse study. Canadian J. Soil Sci., 95(3), 269-285. doi: 10.4141/ CJSS-2014-008.

Boone F. and Veen B., 1994. Mechanisms of crop responses to soil compaction. Soil Compaction in Crop Production, American Society of Agricultural Engineers, St. Joseph, MI, USA.

Busscher W.J., Novak J.M., and Ahmedna M., 2011. Physical effects of organic matter amendment of a southeastern US coastal loamy sand. Soil Sci., 176(12), 661-667. doi: 10.1097/SS.0b013e3182357ca9.

Busscher W.J., Novak J.M., Evans D.E., Watts D.W., Niandou M.A.S., and Ahmedna M., 2010. Influence of pecan biochar on physical properties of a Norfolk loamy sand. Soil Sci., 175(1), 10-14. doi: 10.1097/SS.0b013e3181cb7f46.

Carter M., 1990. Relative measures of soil bulk density to characterize compaction in tillage studies on fine sandy loams. Canadian J. Soil Sci., 70(3), 425-433.

Castellini M., Giglio L., Niedda M., Palumbo A.D., and Ventrella D., 2015. Impact of biochar addition on the physical and hydraulic properties of a clay soil. Soil Till. Res., 154, 1-13. doi: 10.1016/j.still.2015.06.016.

Chen G. and Weil R.R., 2011. Root growth and yield of maize as affected by soil compaction and cover crops. Soil Till. Res., 117, 17-27.

Cimò G., Kucerik J., Berns A.E., Schaumann G.E., Alonzo G., and Conte P., 2014. Effect of heating time and temperature on the chemical characteristics of biochar from poultry manure. J. Agricultural and Food Chem., 62(8), 1912-1918.

Das B.M. and Kassimali A., 2002. Soil mechanics laboratory manual. Oxford University Press, New York, USA. 
Dexter A., 2004. Soil physical quality: Part I. Theory, effects of soil texture, density, and organic matter, and effects on root growth. Geoderma, 120(3), 201-214.

Dexter A.R. and Bird N.R.A., 2000. Methods for predicting the optimum and the range of soil water contents for tillage based on the water retention curve. Soil Till. Res., 57(4), 203-212. doi: 10.1016/S0167-1987(00)00154-9.

Downie A., Crosky A., and Munroe P., 2009. Physical properties of biochar. Biochar for Environmental Management (Eds J. Lechmann, S. Joseph). Science and Technolology, London-Sterling, VA, USA.

Eastman C.M., 2011. Soil Physical Characteristics of an Aeric. Ochraqualf amended with Biochar. PhD. Dissertation, Ohio State University, Columbus, OH, USA, http://rave.ohiolink. edu/etdc/view?acc_num $=$ osu 1316548127

Guo Y., Tang H., Li G., and Xie D., 2014. Effects of cow dung biochar amendment on adsorption and leaching of nutrient from an acid yellow soil irrigated with biogas slurry. Water, Air, Soil Pollution, 225(1), 1-13.

Håkansson I. and Lipiec J., 2000. A review of the usefulness of relative bulk density values in studies of soil structure and compaction. Soil Till. Res., 53(2), 71-85.

Harris W.L., 1971. The soil compaction process. Compaction of Agricultural Soils. American Society of Agricultural Engineers, St. Joseph, MI, USA.

Hu Q., Yang H., Yao D., Zhu D., Wang X., Shao J., and Chen H., 2016. The densification of bio-char: Effect of pyrolysis temperature on the qualities of pellets. Bioresource Technology, 200, 521-527. doi: 10.1016/j.biortech.2015.10.077.

Jeffery S., Verheijen F.G.A., van der Veldea M., and Bastos A.C., 2011. A quantitative review of the effects of biochar application to soils on crop productivity using meta-analysis. Agriculture, Ecosystems Environ., 144(1), 175-187. doi: 10.1016/j.agee.2011.08.015.

Karhu K., Mattila T., Bergstrom I., and Regina K., 2011. Biochar addition to agricultural soil increased $\mathrm{CH}_{4}$ uptake and water holding capacity - Results from a short-term pilot field study. Agriculture, Ecosystems Environ., 140(1-2), 309-313. doi: 10.1016/j.agee.2010.12.005.

Keller T. and Dexter A.R., 2012. Plastic limits of agricultural soils as functions of soil texture and organic matter content. Soil Res., 50(1), 7-17.

Laird D.A., Fleming P., Davis D.D., Horton R., Wang B., and Karlen D.L., 2010. Impact of biochar amendments on the quality of a typical Midwestern agricultural soil. Geoderma, 158(3-4), 443-449. doi: 10.1016/j.geoderma.2010.05.013.

Liu Z., Dugan B., Masiello C.A., Barnes R.T., Gallagher M.E., and Gonnermann H., 2016. Impacts of biochar concentration and particle size on hydraulic conductivity and DOC leaching of biochar-sand mixtures. J. Hydrology, 533, 461472. doi: 10.1016/j.jhydrol.2015.12.007.

Lu S.-G., Sun F.-F., and Zong Y.-T., 2014. Effect of rice husk biochar and coal fly ash on some physical properties of expansive clayey soil (Vertisol). Catena, 114, 37-44.

Mapfumo E. and Chanasyk D.S., 1998. Guidelines for safe trafficking and cultivation, and resistance-density-moisture relations of three disturbed soils from Alberta. Soil Till. Res., 46(3-4), 193-202. doi: 10.1016/S0167-1987(98)00100-7.

Mosaddeghi M.R., Morshedizad M., Mahboubi A.A., Dexter A.R., and Schulin R., 2009. Laboratory evaluation of a model for soil crumbling for prediction of the optimum soil water content for tillage. Soil Till. Res., 105(2), 242250. doi: 10.1016/j.still.2009.08.005.

Mueller L., Schindler U., Fausey N.R., and Lal R., 2003. Comparison of methods for estimating maximum soil water content for optimum workability. Soil Till. Res., 72(1), 9-20. doi: 10.1016/S0167-1987(03)00046-1.

Mukherjee A., Lal R., and Zimmerman A.R., 2014. Impacts of 1.5-year field aging on biochar, humic acid, and water treatment residual amended soil. Soil Science, 179(7), 333-339. doi: 10.1097/SS.0000000000000076.

Müller F., Peukert W., Polke R., and Stenger F., 2004. Dispersing nanoparticles in liquids. Int. J. Mineral Proc., 74, S31-S41.

Muller L., Tille P., and Kretschmer H., 1990. Trafficability and workability of alluvial clay soils in response to drainage status. Soil Till. Res., 16(3), 273-287.

Obia A., Mulder J., Martinsen V., Cornelissen G., and Borresen T., 2016. In situ effects of biochar on aggregation, water retention and porosity in light-textured tropical soils. Soil Till. Res., 155, 35-44. doi: 10.1016/j.still.2015.08.002.

Ohu J.O., Raghavan G., and McKyes E., 1985. Peatmoss effect on the physical and hydraulic characteristics of compacted soils. Transactions of the ASAE, 28(2), 420-0424.

Oren A.H., 2014. Estimating compaction parameters of clayey soils from sediment volume test. Applied Clay Science, 101, 68-72. doi: 10.1016/j.clay.2014.07.019.

Reddy K.R., Yaghoubi P., and Yukselen-Aksoy Y., 2015. Effects of biochar amendment on geotechnical properties of landfill cover soil. Waste Manag. Res., 0734242X15580192.

Singh B. and Malhi S., 2006. Response of soil physical properties to tillage and residue management on two soils in a cool temperate environment. Soil Till. Res., 85(1), 143-153.

Smedema L.K., 1993. Drainage performance and soil management. Soil Technology, 6(2), 183-189. doi: 10.1016/09333630(93)90007-2.

Wagner L.E., Ambe N.M., and Barnes P., 1992. Tillage-induced soil aggregate status as influenced by water content. Trans. Am. Society Agric. Eng., 35(2), 499-504.

Yargicoglu E.N., Sadasivam B.Y., Reddy K.R., and Spokas K., 2015. Physical and chemical characterization of waste wood derived biochars. Waste Manag., 36, 256-268. doi: 10.1016/j.wasman.2014.10.029.

Yuan H., Lu T., Wang Y., Huang H., and Chen Y., 2014. Influence of pyrolysis temperature and holding time on properties of biochar derived from medicinal herb (radix isatidis) residue and its effect on soil $\mathrm{CO}_{2}$ emission. J. Analytical Applied Pyrolysis, 110, 277-284.

Zhao Y., Krzic M., Bulmer C. E., Schmidt M. G., and Simard S.W., 2010. Relative bulk density as a measure of compaction and its influence on tree height. Canadian J. Forest Res., 40(9), 1724-1735.

Zong Y., Xiao Q., and Lu S., 2016. Acidity, water retention, and mechanical physical quality of a strongly acidic Ultisol amended with biochars derived from different feedstocks. J. Soils Sediments, 16(1), 177-190. 